\title{
SPECIAL EXHIBITIONS
} THE ART INSTITUTE OF CHICAGO, DECEMBER 12 1916 TO JANUARY 2, 1917

PAINTINGS BY JOHN W. ALEXANDER SCULPTURE BY CHESTER BEACH PAINTINGS BY CALIFORNIA ARTISTS PAINTINGS BY WILSON IRVINE PAINTINGS BY EDWARD W. REDFIELD PAINTINGS, DRAWINGS AND SKETCHES BY MAURICE STERNE 


SPECIAL EXHIBITIONS OF WORK BY

THE FOLLOWING ARTISTS

PAINTINGS BY JOHN W. ALEXANDER SCULPTURE BY CHESTER BEACH PAINTINGS BY CALIFORNIA ARTISTS PAINTINGS BY WILSON IRVINE PAINTINGS BY EDWARD W. REDFIELD PAINTINGS, DRAWINGS AND SKETCHES BY MAURICE STERNE

THE ART INSTITUTE OF CHICAGO DEC. 12, 1916 TO JAN. 2, 1917

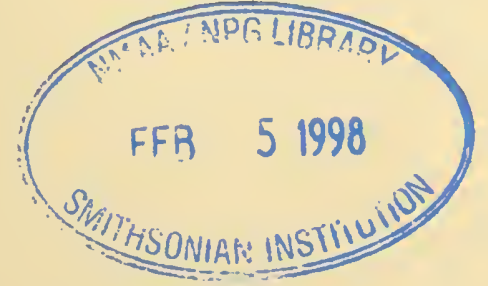



PAINTINGS BY JOHN WHITE ALEXANDER 
TOHN W. ALEXANDER. Born, Pittsburgh, Pennsylvania, I 856. Died, New York, May 3 I, 1915. Studied at the Royal Academy, Munich, and with Frank Duveneck. Sociétaire of Société Nationale des Beaux Arts, Paris; Member of the International Society of Sculptors, Painters and Gravers, London; Société Nouvelle, Paris; Sociétaire of the Royal Society of Fine Arts, Brussels; President of the National Acadeny of Design, New York; President of the National Academy Association; President of the National Society of Mural Painters, New York; ExPresident of the National Institute of Arts and Letters, New York; American Academy of Arts and Letters; Vice-President of the National Fine Arts Federation, Washington, D. C.; Member of the Architectural League, Fine Arts Federation and Fine Arts Society, New York; Honorary Member of the Secession Society, Munich, and of the Secession Society, Vienna; Honorary Member of the Royal Society of British Artists, of the American Institute of Architects and of the New York Society of Illustrators; President of the School Art League, New York; Trustee of the New York Public Library; Ex-President of the MacDowell Club, New York; Trustee of the Metropolitan Museum of Art; Trustee of the American Academy in Rome; Chevalier of the Legion of Honor, France; Honorary Degree of Master of Arts, Princeton University, I 892, and of Doctor of Literature, Princeton, 1909.

Represented in the Luxembourg, Paris; in collections in St. Petersburg, Odessa and Vienna; Metropolitan Museum of Art, New York; The Art Institute of Chicago; Rhode Island School of Design, Providence; Pennsylvania Academy of the Fine Arts, 


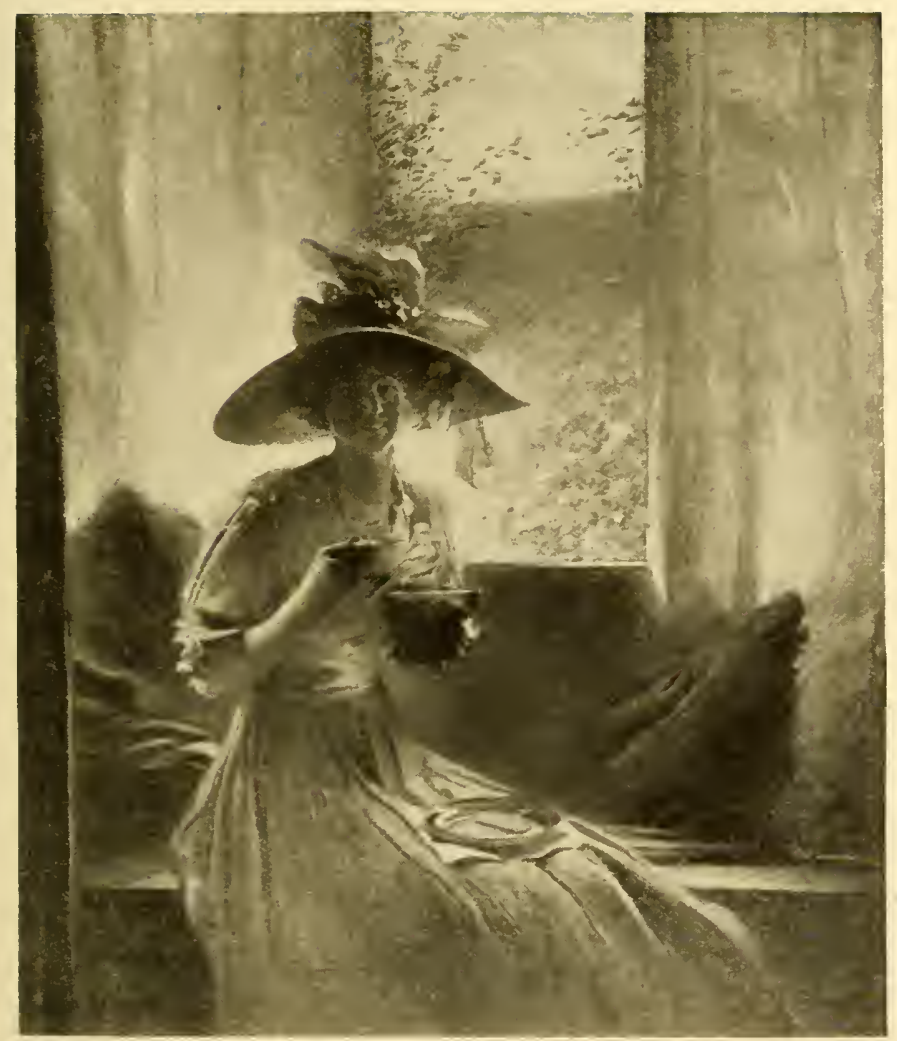

THE GOSSIP - JOHN W. ALEXANDER 
Philadelphia; Museum of Fine Arts, Boston; Cincinnati Museum Association; Carnegie Institute, Pittsburgh; Society of the Fine Arts, Minneapolis; Wilstach Gallery, Philadelphia; National Gallery of Art, Washington, D. C.; City Art Museum, St. Louis, Harvard, Yale, Princeton and Columbia Universities; Wheaton Seminary, Norton, Massachusetts: Radcliffe, Mt. Holyoke and Bowdoin Colleges; Library of Congress, Washington, D. C. ; Mt. Auburn Association, Boston; State House, Albany, New York; State House, Trenton, New Jersey; Stevens Institute, Hoboken, New Jersey; Bar Association of New Jersey, Elizabeth, New Jersey; Chamber of Commerce, New York; Surrogate's Court, New York; University, Calumet and Century Clubs, New York.

Bronze Medal, Munich Royal Academy; Temple Gold Medal, Pennsylvania Academy of the Fine Arts, I 897; Lippincott Prize, Pennsylvania Academy of the Fine Arts, I899; Gold Medal, Exposition Universelle, Paris, 1900; Carnegie Prize, Society of American Artists, I90I ; Gold Medal, Pan-American Exposition, Buffalo, I901; Gold Medal of Honor, Pennsylvania Academy of the Fine Arts, 1903; Corcoran Prize, Washington, D. C., I903; Gold Medal, Universal Exposition, St. Louis, I904; Medal of the first class, Carnegie Institute, Pittsburgh, I9I I; Medal of Honor, Panama-Pacific International Exposition, San Francisco, I9I 5 . 


\section{PORTRAIT OF WALT WHITMAN}

Lent by the Metropolitan Museum of Art, New York.

2 "ISABELla OR THE POT OF BASIL"

Lent by the Museum of Fine Arts, Boston.

3 PORTRAIT OF MISS MARY C. WHEELER

Lent by Miss Wheeler, Providence, R. I.

4 PORTRAIT OF MRS. WHEATON

Lent by Wheaton College, Norton, Mass.

5 PORTRAIT OF HELEN BEATTY

Lent by John W. Beatty, Esq.

6 STUDY HEAD OF A MUNICH PEASANT

Lent by Julius Rolshoven, Esq.

7 SKETCH OF BOOTH TARKINGTON

Lent by Quadrangle Club, Princeton, N. J.

8 THE MOTHER

Lent by Estate of John W. Alexander.

9 LANDSCAPE. (CORNISH, N. H.)

Lent by Estate of John W. Alexander.

10 MARINE. (MOONLIGHT)

Lent by Mrs. John W. Alexander.

11 THE TENTH MUSE

Lent by Mr. James W. Alexander.

12 ON A BALCONY

Lent by Mr. James W. Alexander.

13 THE GOSSIP

Lent by Estate of John W. Alexander. 
14 LANDSCAPE

Lent by Estate of John W. Alexander.

15 JOSEPH JEFFERSON AS BOB ACRES

Lent by Estate of John W. Alexander.

16 PEONIES

Lent by Mrs. John W. Alexander.

I7 MEMORIES

Lent by Mrs. John W. Alexander.

18 JULIETTE

Lent by Estate of John W. Alexander.

19 THE BLACK CAT

Lent by Mrs. John W. Alexander.

20 OLD COLE

Lent by Estate of John W. Alexander.

21 THE GLASS BOWL

Lent by Estate of John W. Alexander.

22 THE BLUE BOWL

Lent by Estate of John W. Alexander.

23 THE GREEN GOWN

Lent by Estate of John W. Alexander.

24 A ROSE

Lent by Estate of John W. Alexander.

25 REFLECTIONS

Lent by Estate of John W. Alexander.

26 WHITE BIRCHES

Lent by Miss Elizabeth Averell. 


\section{IN THE ORCHARD}

Lent by Mrs. John W. Alexander.

28 FLOWERS

Lent by Estate of John W. Alexander.

\section{LANDSCAPE}

Lent by Estate of John W. Alexander.

30 BIRCHES (CORNISH, N. H.)

Lent by Mrs. A. G. Hoffman. 

SCULPTURE BY CHESTER BEACH 
Chester BEACH, 207 East 17 th Street, New York City. Born, San Francisco, California, May 23, I88I. Studied in Rome, and pupil of Verlet and Roland in Paris. Member: National Academy of Design; Architectural Society of New York; National Sculpture Society; Numismatic Society of New York. Awards: Helen Foster Barnett prize for sculpture, 1909; Silver Medal, Panama-Pacific International Exposition, San Francisco, 1915; Honorable Mention, Art Institute of Chicago, 1915.

\section{SCULPTURE BY CHESTER BEACH}

MARBLES

3I SACRED FIRE

32 CLOUD FORMS

33 LIFE'S VORTEX

34 STUDY FOR LIFE'S VORTEX. No. 1

35 STUDY FOR LIFE'S VORTEX. No. 2

36 STUDY HEAD; MYSTERY

37 STUDY HEAD; PATRICIAN

38 WAVE HEAD

39 GREAT-GRANDMOTHER

40 THREE WEEKS OLD

41 CRYING-THREE DAYS OLD

42 TWO DAYS OLD 


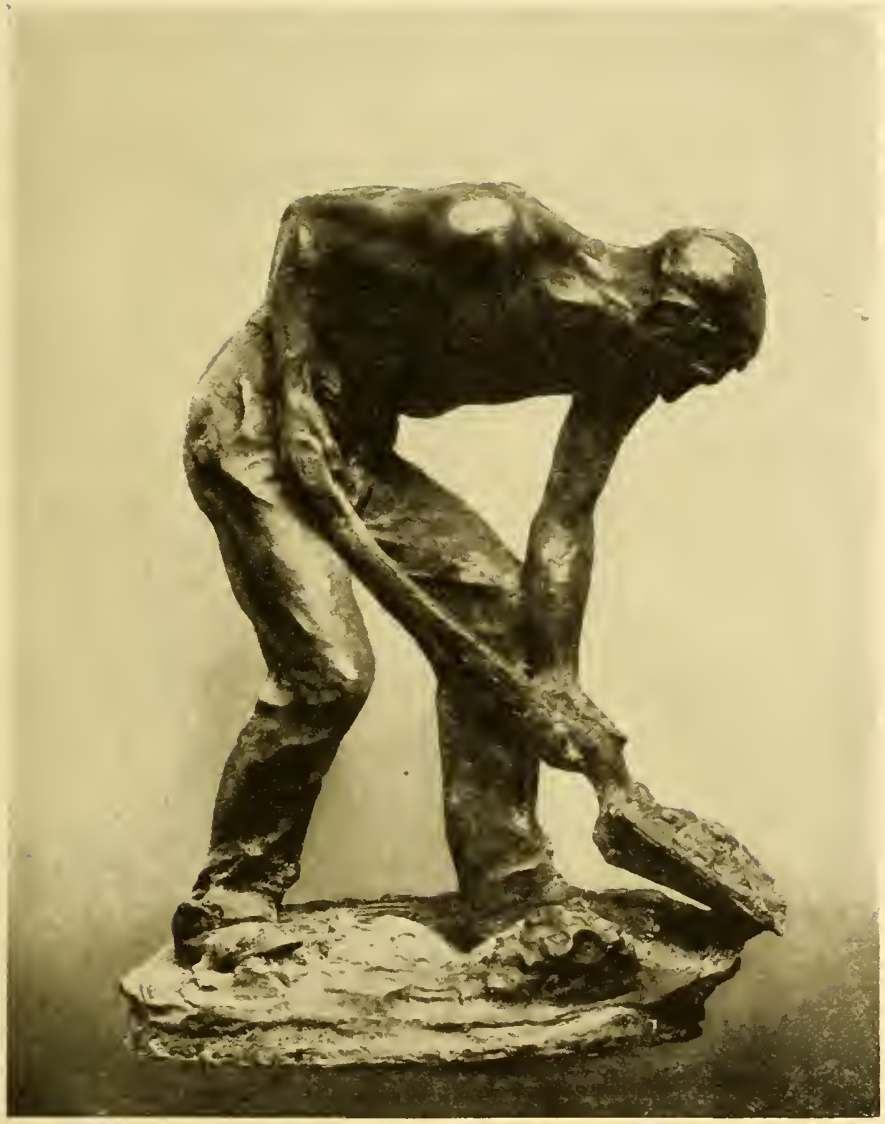

THE STOKER-CHESTER BEACH 
43 STUDY HEAD; YOUNG GIRL

44 CROWING

45 DAWN AND EVENING

46 SNOW DANCE

47 MIST FIGURE

48 WAVE HORSES

49 UNVEILING OF DAWN

50 ACHIEVEMENT

51 DAWN

52 MERMAID

53 THE NEW BORN

54 NATHALIE

BRONZES

55 GOBLINS

56 SPIRIT OF THE PINES

57 AUTUMN LEAVES

58 TORSO: MALE

59 TORSO: FEMALE

60 STUDY HEAD: SACRED FIRE

61 RIVER BANK

62 SWIMMIN $^{*}$ 


\section{SILENUS}

64 CHILD AT THREE WEEKS

65 NIGHT

66 FOUR SEALS: $a$ STUDY $b$ MERCURY

c STUDY FOR VORTEX $d$ ROME

67 BEFORE THE WIND

68 BACCHUS AND KID

69 ROUGH SEA

70 STUDY FOR CLOUD

71 LE MASQUE

72 NERO

73 WOODS FIGURE

74 STOKER

75 THE BIG WAVE

76 BACCHANTE MASK

7? FRAME OF MEDALLIONS

78 ASLEEP

79 BEYOND 

PAINTINGS BY WILSON IRVINE 
WILSON IRVIIIE, 2657 West $15^{\text {th }}$ Street, Chicago. Born January 28, I869, Byron, Illinois. Studied at The Art Institute of Chicago. Ex.President of the Chicago Society of Artists and the Palette and Chisel Club, Chicago. Member: The Artists' Guild; The Arts Club; The Cliff Dwellers; The Commission for the Encouragement of Local Art, Chicago.

Represented in the collection of The Art Institute of Chicago; Municipal Art League; Union League Club; Arché Club; Chicago Woman's Club; Englewood Woman's Club, Chicago.

Awards: Martin B. Cahn Prize, The Art Institute of Chicago, I912; Clyde M. Carr Prize, The Art Institute of Chicago, 1915; Silver Medal, PanamaPacific International Exposition, San Francisco, 1915; Silver Medal of the Chicago Society of Artists, I9I6; First Prize of the Municipal Art League, Palette and Chisel Club Exhibition, I9I6.

80 VIEW OF SALEM, CONNECTICUT

81 BY-WAYS OF IKE MARVEL

82 IN HER GOLDEN TUNIC

83 ROAD TO AUNT BECKY'S

84 UNDER THE CHESTNUT TREE

85 A SUMMER AFTERNOON

86 THE VONNOH HOUSE

87 THE SAYBROOK LIGHT 


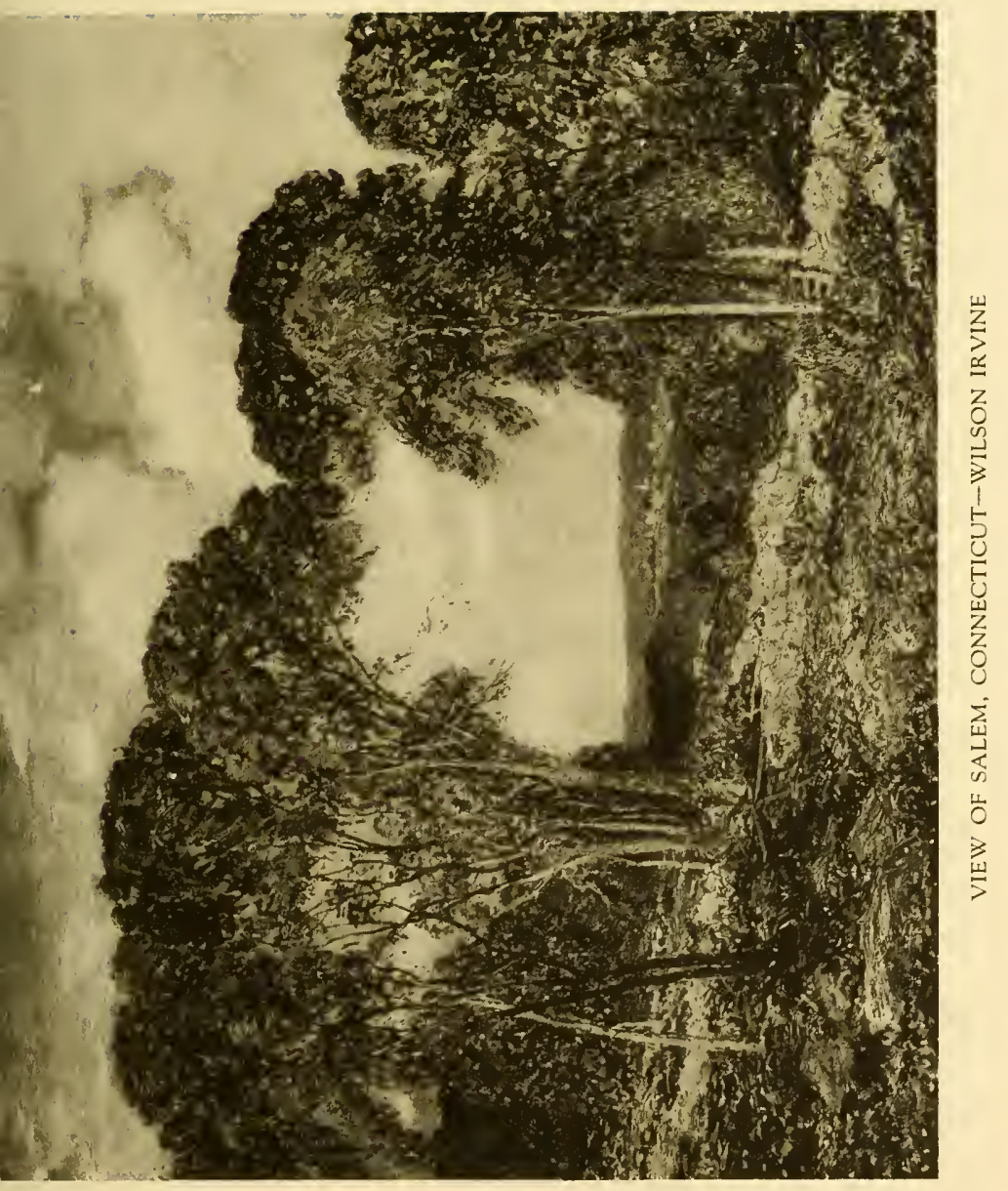


88 THE SLEEPING TARN

89 ON WOODBRIDGE HILL

90 IN THE WINTER BERTH

93 APRIL DAYS

94 THE TAWNY HILL

95 FIELDS BY THE SEA

96 AN OLD SHAGBARK

97 A MEADOW POOL

98 THE TREMULOUS GLEAM

99 IN NEW ENGLAND

100 THE HOME PORT

101 THE BLACK-BIRDS' RETURN

102 NOANK

103 THE WOODLAND POOL

104 UNDER THE SUMMER SUN

105 WOODS EXPECTANT

106 MOUNT ARCHER'S CREST

107 THE WOODLAND BROOK 
PAINTINGS BY EDWARD W. REDFIELD 
G DWARD W. REDFIELD, CentreBridge, Bucks County, Pennsylvania. Born December 19, I868, Bridgeville, Delaware. Pupil of The Pennsylvania Academy of the Fine Arts; Bouguereau and RobertFleury in Paris. Member: Society of American Artists, 1903; National Institute of Arts and Letters; Philadelphia Art Club; Fellowship, The Pennsylvania Academy of the Fine Arts; Salmagundi Club. Awards: Medal, Philadelphia Art Club, 1896; bronze medal, Paris Exposition, 1900; bronze medal, Pan-American Exposition, 1901; Temple medal, The Pennsylvania Academy of the Fine Arts, 1903; second Hallgarten prize, National Academy of Design, 1904; Shaw Fund prize, Society of American Artists, I904; silver medal, St. Louis Exposition, 1904; Sesnan gold medal, The Pennsylvania Academy of the Fine Arts, 1905; second medal, Carnegie Institute, 1905; Webb prize, Society of American Artists, 1906; gold medal of honor, The Pennsylvania Academy of the Fine Arts, 1907; Fischer prize and bronze medal, Corcoran Gallery, 1907; first W. A. Clark prize and gold medal, Corcoran Gallery, I908; honorable mention, Paris Salon, 1908; third class medal, Paris Salon, 1909; second Harris medal, The Art Institute of Chicago, I909; gold medal, Buenos Aires Exposition, 1910; Lippincott prize, The Pennsylvania Academy of the Fine Arts, 1912; gold medal, Society of Washington Artists, 1913; Palmer gold medal $(\$ 1,000)$, The Art Institute of Chicago, 1913; gold medal $(\$ 1,500)$, Carnegie Institute, 1914 ; hors concours (jury of awards), Panama-Pacific International Exposition, 191 5. Represented in the Luxembourg, Paris; Corcoran Gallery of Art, Washington, D. C.; Cincinnati Museum Association; Carnegie Institute, Pittsburgh; The Brooklyn Museum; The 


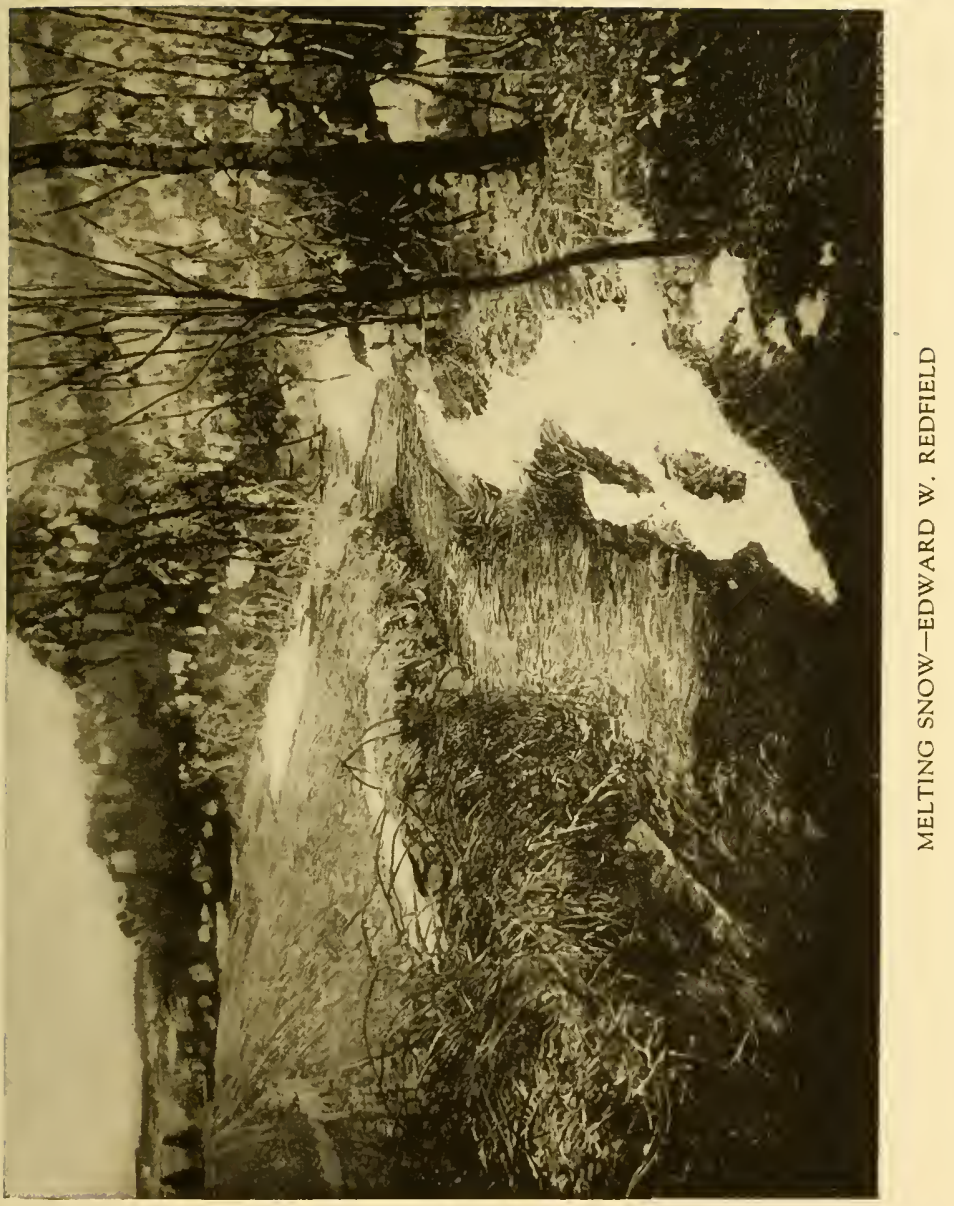


Pennsylvania Academy of the Fine Arts; Museum of Fine Arts, Boston ; John Herron Art Institute, Indianapolis; Detroit Museum of Art; The Art Institute of Chicago; Buffalo Fine Arts Academy; Minneapolis Institute of Arts; Rhode Island School of Design, Providence.

108 CANAL IN WINTER

109 THE VALLEY IN MAY

110 SPRING

111 THE FORBIDDEN GARDEN

112 THE BROOK IN WINTER

113 APPROACHING SPRING

114 AUTUMN

115 GARDEN BY THE RIVER

116 IN THE ORCHARD

117 THE BROOK; GRAY DAY

118 IN THE WOODS

119 THE ROAD IN SUMMER

120 OVERLOOKING THE CITY

121 SLEIGH-BELLS

122 THE EAST RIVER

123 THE GRAY VEIL 
124 INDIAN SUMMER

125 THE DESERTED FARM

126 MORNING IN THE VILLAGE

127 CENTRE BRIDGE

128 BETWEEN DAYLIGHT AND DARKNESS

129 IN THE CLEARING

130 BROOKLYN BRIDGE

131 WOODLAND BROOK

132 A VILLAGE IN FRANCE

133 THE FARM-HOUSE

134 THE BROOK AND MEADOW

135 THE CANAL AT CENTRE BRIDGE

136 THE ROAD TO CALAIS

137 AT THE_FOOT OF THE MOUNTAIN

138 SNOW-STORM

139 WINTER 

PAINT'NGS, SKETCHES AND DRAWINGS BY MAURICE STERNE 

trator and teacher. Born, Libau, Russia, I 877. Came to New York in I 889. Pupil of National Academy of Design and other schools in New York. Has traveled extensively in Europe. Made special study of the people of Bali, one of the East Indian Islands. Represented in following museums: Kaiser Friedrich Museum, Berlin; Metropolitan Museum, New York; Carnegie Institute, Pittsburgh; Rhode Island School of Design, Providence.

\section{FOREWORD}

Many will wonder where and what is Bali, and I have been asked to say something about it. For two reasons this is very difficult. First: My twenty months' sojourn there was an experience of the senses, and how is one to describe the perfume of a flower, strains of music, or the different sensations of touch? Second: For comprehension, similarity of experience is essential. Imagination is of little help when called upon to realize forms, colors and sounds, unlike anything we are familiar with, and Bali is so very unlike any other place in the West or in the East.

Much which is comprehensible can of course be said. For instance, geographically it is one of the many islands belonging to the group known as the Indian Archipelago, about eight degrees south of the equator, between Java and Lombok. It is populated by Malays, and almost two-thirds of it is jungle and virgin forest. The people are silent, liberty loving, and proud. When Java at the end of the fifteenth century was invaded by the Mohammedans, the Javanese fled to this thinly 


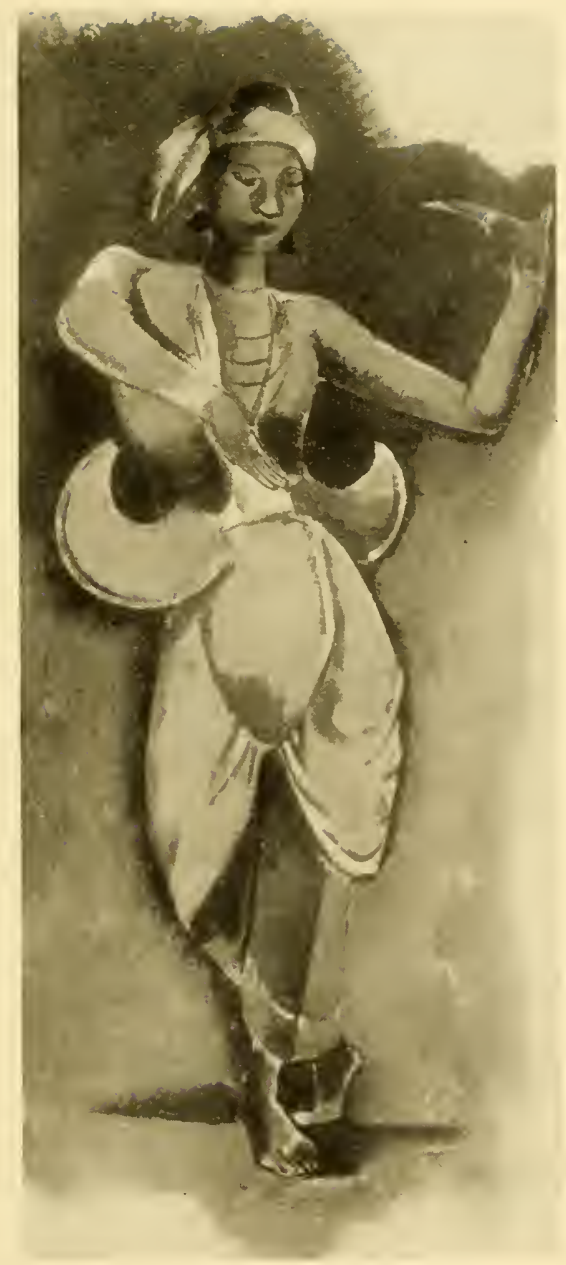

BURMESE DANCER-MAURICE STERNE 
populated neighboring island with their customs and religion, leaving all worldly possessions behind them. This spirit was again shown eight years ago, when the price of cocoanuts rose, and Holland decided to annex Bali. Several thousand of the highest caste of the population arrayed themselves as for a temple festival, with precious golden bowls, silk brocades, lances and spears, and went to meet the conquering Dutch troops, with their guns and powder. At a given signal the men, women and children drew their flame-shaped krisses and killed themselves.

But wherein, it will be asked, does Bali differ from her neighbors-from Java, Sumatra, Celebes? The Balinese alone of all the inhabitants of the archipelago have to this day retained the Hindu religion. Islam, with its art barrenness, has been imposed upon the neighboring islands. In abstract, austere Mohammedanism there is little room for art. It has sunk to mere decoration, tolerated as a prayer-rug under the feet of the devotee; whereas to the impassioned Hindu it is a means of getting closer to God. With them art is religion's language, understood by God. Symmetry is its words, rhythm its phrases, perfect balance its sentences. Like the immense active volcano towering above the terraced rice-fields and teeming tropical vegetation, Religion, passionate and agitated, projects from their daily tasks. The same fire or unknown force which from the bowels of the earth exhales steam and molten lava from the mouth of the crater gushes from the heart of the frenzied worshiper, leaving him prostrate and in a deathly stupor at the feet of his deity. A fiery, emotional, passionate religion, and the gentler Gods of Hindustan have been almost forgotten. Know- 
ing the power of destruction, Brahma the Creator and Vishnu the Preserver have sunk to a secondary place. Shiva the Destroyer is honored most. The religious rites are for the most part hysteric trances or frenzies, and the elements are symbolically expressed in their sacred dances at the temple festivals. In the largest painting shown in the present exhibition, I have tried to express one of these dances. Fire, Water and Air are represented by priests and priestesses carrying incense burners, bowls of water and fans. Rapid upwarl Hickering action of flames, threatening sinuous flow of water, and irresistible air, are expressed in rhythmic movement and significant gesture.

Not only religious functions, but the commonest pursuits, are carried out with a grace, dignity and grandeur familiar to us from the finest ancient art alone. What, for instance, could be more prosaic than buying or selling? But here ducks, pigs and fruit are sold with an air suggestive of sacrifice, incense, flowers, and the altar. In geometric designs they arrange their fish for sale; the fruit is piled up in perfect pyramids. Like golden queens they sit enthroned among the richly colored stuffs, and not unlike goddesses they emerge from the miniature mountains of rice. Like splendid Persian rugs, spread in the intense shade of the gigantic banyan trees, are the bazaars. Here nature has become the medium of art, and art the expression of nature. Art is hardly needed where the aesthetic sense is stimulated by life, and not, as in the West, by art alone.

Maurice Sterne. 
OIL PAINTINGS

140 KNEELING OLD MAN

141 WOMAN CARRYING DISH

142 BALINESE DANDY

143 WATER CARRIER

144 WOMAN AT BAZAAR

145 MOTHER WITH TWINS

146 GIRL WITH BANANAS

147 WOMAN STANDING

148 MOTHER WITH BOY

149 YOUNG WOMAN SEEN IN PROFILE

150 BALINESE ASLEEP

151 BURMESE FOUNDLING CHILD

152 MAN WITH DAGGER

153 WOMAN CARRYING BASKET

154 CEREMONIAL HEAD-GEAR

155 OLD WOMAN CARRYING COCOANUTS

156 TWO GIRLS WALKING TO MARKET

157 PRINCE TAKING LEAVE OF PRINCESS

158 RESTING AT BAZAAR

159 TEMPLE FEAST 
160 BOWL OF FRUIT

161 TEMPLE SCENE

162 HEAD OF YOUNG BOY

163 IDOL

164 DRESSING FOR THE DANCE

165 THREE BOYS

166 SKETCH OF A MAN

167 BURMESE ON THE GANGES

168 BAZAAR AT BALI

169 BURMESE NUN

170 THREE WOMEN

171 SKETCH: BALI

172 THE VENDER

173 SKETCH: BAZAAR

174 WOMAN

175 WOMAN WITH BASKET

176 MARKET SCENE

177 DANCE OF THE SACRED ELEMENTS

178 WOMAN DRESSING

179 WOMAN WALKING

180 WOMAN WITH BASKET 
181 MOTHER AND CHILD

182 TWO DANCERS

COLORED SKETCHES

183 BURMESE DANCER

184 DANCING GIRL RESTING

185 BURMESE NUN

186 WOMAN AT TEMPLE FEAST

187 IDOL

188 LANDSCAPE WITH DEER

189 BURMESE WOMEN

190 WOMAN SEEN FROM BEHIND

191 TEMPLE FEAST

192 SEATED WOMAN

193 YOUNG GIRL

DRAWINGS

194 GIRL DANCING, WITH INCENSE

195 SEATED WOMAN

196 RELIGIOUS DANCE

197 WOMAN MEDITATING

198 WOMAN DRESSING 
199 NUDE ASLEEP

200 YOUNG GIRL

201 STUDY FOR DECORATION

202 ROMAN MODEL

203 BURMESE DANCER

204 BURMESE DANCER

205 BALINESE DANCER

206 DANCING GIRL

207 YOUNG GIRL DANCING

208 NUDE WOMAN SEATED

209 MAN THRASHING WHEAT FOR HARVEST

210 MAN WITH SWORD

211 MAN LEADING OXEN

212 STUDY FOR DECORATION

213 STUDY FOR DECORATION

2 I4 HEAD OF AN OLD WOMAN

215 OLD WOMAN SEATED

216 BALINESE WOMAN SEATED

217 WOMEN AT PLAY

218 SLEEPING WOMAN

219 THE PRINCESS 
220 STUDY OF YOUNG GIRL

221 YOUNG BALINESE ASLEEP

222 SKETCH FOR A FRIEZE

223 MRS. MABEL DODGE, RECUMBENT

224 MRS. MABEL DODGE, ON A COUCH

225 MRS. MABEL DODGE, WITH HANDS OVER FACE 
PAINTINGS BY CALIFORNIA ARTISTS

SELECTED BY

J. NILSEN LAURVIK

DIRECTOR OF THE

SAN FRANCISCO ART ASSOCIATION 
ROWENA MEEKS ABDY

226 STILL-LIFE

CARL OSCAR BORG

227 UNDER THE STARS

228 LANDSCAPE

229 CAMPAGNA ROMANA

MAURICE BRAUN

230 VIEW OF MISSION VALLEY

ANNE M. BREMER

231 THE LACQUER SCREEN

232 FOUNTAIN OF MIRACLES

233 YELLOW AND BRONZE

BETTY DEJONG

234 GRANDMOTHER AND CHILD

235 BEATRIX

236 THE BALLET GIRL

MAURICE DEL MUE

237 LAND OF THE AMORANTH, NO. 2

238 LAKE THAN-A-YA, YOSEMITE 


\section{MAYNARD DIXON}

239 THE STREAM

240 LONG VALLEY, OREGON

$$
\text { HELENA DUNLAP }
$$

241 AFTER THE STORM

242 STILL STREAM

E. CHARLTON FORTUNE

243 THE SAN GABRIEL VINE

$$
\text { ARMIN C. HANSEN }
$$

244 PORTRAIT

245 THE MISSISSIPPI PILOT

246 THE BELATED BOAT

CLARENCE K. HINKLE

247 SEA CLIFF

CLARK HOBART

248 IN THE GARDEN

249 UP CARMEL VALLEY

250 BETWEEN SHOWERS: MONTEREY

AMADEE JOULLIN

251 INGLESIDE 
FLORENCE LUNDBORG

252 A BOWL OF COLOR

MAVIER MARTINEZ

253 PIEDMONT HILLS

254 PIEDMONT HILLS

255 BY THE LAKE SIDE

ARTHUR F. MATHEWS

256 THE MANDARIN

JULES MERSFELDER

257 PIEDMONT HILLS

PERHAM W. NAHL

258 DESPAIR

BRUCE NELSON

259 MONTEREY COAST

GERTRUDE PARTINGTON

260 PORTRAIT: MRS. JACK ALLAN PARTINGTON

\section{R. L. PARTINGTON}

261 A BIT OF ANGELS' CAMP

Lent by Frank H. Powers, Esq. 


\section{ORRIN PECK}

262 LADY FLORA X

\section{GOTTARDO F. P. PIAZZONI}

263 THE SLEEPING CITY

Lent by Mrs. Leon Sloss

\section{H. V. POOR}

264 PORTRAIT

265 GIRL IN WHITE

266 MOUNT EL TORRO

267 SLEEPING BABY

\section{BRUCE PORTER}

268 A STUDY

\section{LEE RANDOLPH}

269 GIRL WITH POPPY

270 VIADUCT IN FOG

\section{JOSEPH RAEPHAEL}

271 THE GARDENER

272 MEDITATING

273 IN THE ORCHARD 
MATTEO SANDONA

274 THE KIMONO

GENEVE RIXFORD SARGEANT

275 MARGARET

HENRIETTA M. SHORE

276 GIRL WITH FRUIT

277 LITTLE GIRLS

FRANK VAN SLOUN

278 PORTRAIT OF AN ACTOR

TIMOTHY MILTON WULFF

279 PORTRAIT 


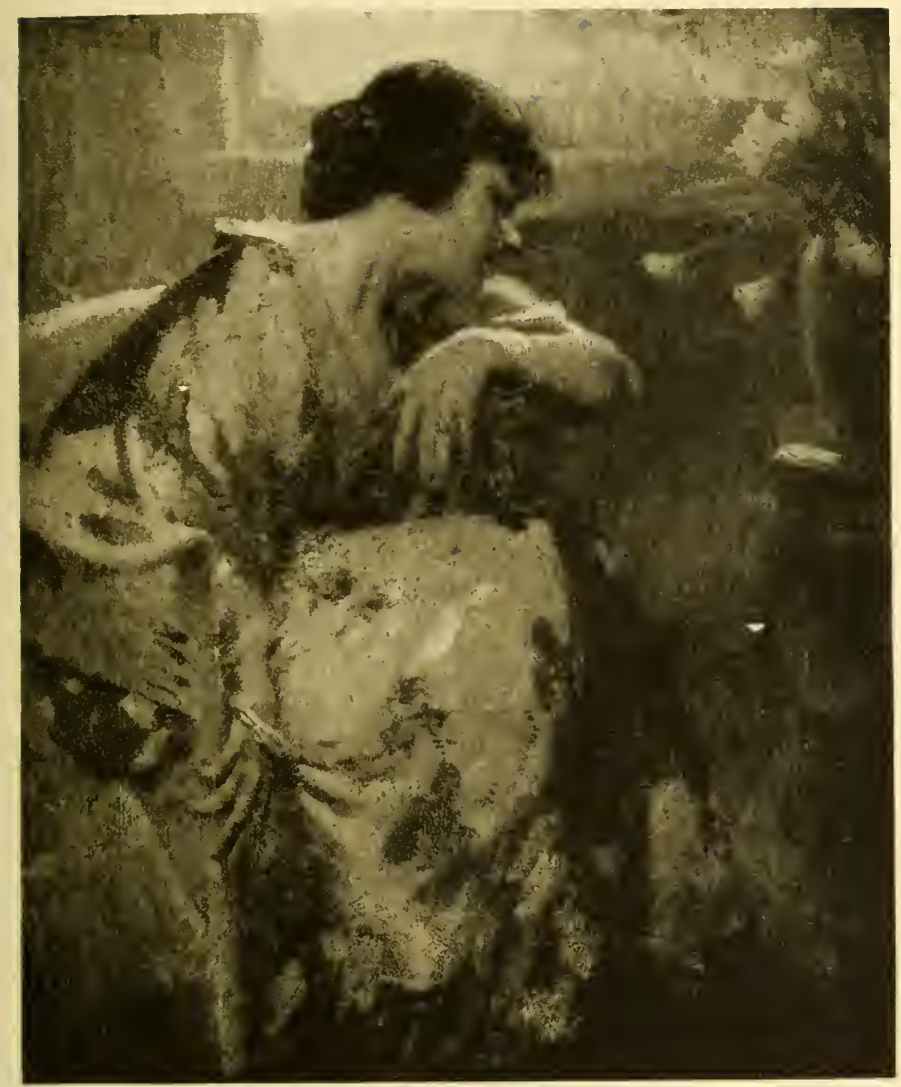

THE KIMONO MATTEO SANDONA 


SMITHSONIAN INSTITUTION LIBRARIES

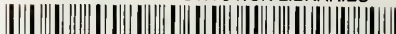

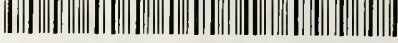

39088008650772 